\title{
The Chemokine Receptors CXCR3 and CCR5 Mark Subsets of T Cells Associated with Certain Inflammatory Reactions
}

\author{
Shixin Qin, ${ }^{\star}$ James B. Rottman, ${ }^{*}$ Paul Myers, ${ }^{\star}$ Nasim Kassam, ${ }^{\star}$ Michael Weinblatt, ${ }^{\ddagger}$ Marcel Loetscher,, Alisa E. Koch, ${ }^{\S}$ \\ Bernhard Moser, and Charles R. Mackay* \\ *LeukoSite, Inc., Cambridge, Massachusetts 02142; ${ }^{\ddagger}$ Brigham and Women’s Hospital, Boston, Massachusetts 02150; ${ }^{\circledR}$ Northwestern \\ University Medical School and Veterans' Administration Chicago Healthcare System, Lakeside Division, Chicago, Illinois 60611; \\ "Theodor-Kocher Institute, University of Bern, CH-3000-Bern-9, Switzerland
}

\begin{abstract}
T cells infiltrating inflammatory sites are usually of the activated/memory type. The precise mechanism for the positioning of these cells within tissues is unclear. Adhesion molecules certainly play a role; however, the intricate control of cell migration appears to be mediated by numerous chemokines and their receptors. Particularly important chemokines for activated/memory $T$ cells are the CXCR3 ligands IP-10 and Mig and the CCR5 ligands RANTES, macrophage inflammatory protein-1 $\alpha$, and macrophage inflammatory protein- $1 \beta$. We raised anti-CXCR3 mAbs and were able to detect high levels of CXCR3 expression on activated $T$ cells. Surprisingly, a proportion of circulating blood $T$ cells, B cells, and natural killer cells also expressed CXCR3. CCR5 showed a similar expression pattern as CXCR3, but was expressed on fewer circulating $T$ cells. Blood $T$ cells expressing CXCR3 (and CCR5) were mostly $\mathrm{CD}^{2} 5 \mathrm{RO}^{+}$, and generally expressed high levels of $\beta 1$ integrins. This phenotype resembled that of $T$ cells infiltrating inflammatory lesions. Immunostaining of $T$ cells in rheumatoid arthritis synovial fluid confirmed that virtually all such $\mathrm{T}$ cells expressed CXCR3 and $\sim 80 \%$ expressed CCR5, representing high enrichment over levels of $\mathrm{CXCR3}^{+}$and $\mathrm{CCR5}^{+} \mathrm{T}$ cells in blood, 35 and $15 \%$, respectively. Analysis by immunohistochemistry of various inflamed tissues gave comparable findings in that virtually all $\mathrm{T}$ cells within the lesions expressed CXCR3, particularly in perivascular regions, whereas far fewer $T$ cells within normal lymph nodes expressed CXCR3 or CCR5. These results demonstrate that the chemokine receptor CXCR3 and CCR5 are markers for T cells associated with certain inflammatory reactions, particularly $\mathrm{TH}-1$ type
\end{abstract}

S. Qin and J.B. Rottman contributed equally to this work.

Address correspondence to Dr. Shixin Qin, LeukoSite, Inc., 215 First Street, Cambridge, MA 02142. Phone: 617-621-9350; FAX: 617621-9349; E-mail: shixin_qin@leukosite.com Charles R. Mackay’s current address is Millennium Biotherapeutics, Cambridge, MA 02139.

Received for publication 6 August 1997 and accepted in revised form 5 December 1997.

J. Clin. Invest.

(c) The American Society for Clinical Investigation, Inc. 0021-9738/98/02/0746/09 \$2.00

Volume 101, Number 4, February 1998, 746-754

http://www.jci.org reactions. Moreover, CXCR3 and CCR5 appear to identify subsets of $\mathrm{T}$ cells in blood with a predilection for homing to these sites. (J. Clin. Invest. 1998. 101:746-754.) Key words: chemokines • inflammation • cell -migration • antibodies -monoclonal $\bullet$ lymphocytes

\section{Introduction}

Leukocyte migration is essential for immune surveillance of the body's tissues, and for focusing immune cells to sites of antigenic challenge. The control of leukocyte migration depends on the combined actions of various adhesion molecules, as well as a vast array of chemotactic cytokines (chemokines) and their receptors. The role of adhesion molecules in leukocyte migration is well appreciated $(1,2)$, whereas that of different chemokines and their receptors is less certain. The chemokine receptors comprise two groups, the CC receptors 1-8 $(\mathrm{CCR} 1-8)^{1}$ that bind $\mathrm{CC}$ chemokines, and the $\mathrm{CXC}$ receptors 1-4 (CXCR1-4), which bind CXC chemokines (3-5). In general, the $\mathrm{CC}$ chemokines and their receptors effect the migration of monocytes, eosinophils, basophils, and T cells (6-8), whereas CXCR1 and CXCR2, which are the two IL-8 receptors, effect the migration of neutrophils (3).

The notion that CXC chemokines are generally poor chemoattractants for $\mathrm{T}$ cells has been challenged recently. Thus the CXC chemokine SDF-1 is a potent chemoattractant for blood T cells (9), and binds to CXCR4 $(10,11)$, a broadly expressed chemokine receptor (12). The CXC chemokines IP-10 and Mig, both inducible by interferon- $\gamma$ during inflammation, also are effective $\mathrm{T}$ cell chemoattractants (13-15). IP-10 and Mig attract activated T cells, but not resting T cells. These two chemokines induce an increase in intracellular calcium by cells transfected with the cDNA for the chemokine receptor CXCR3, indicating that this is the likely IP-10/Mig receptor on T cells (14). By Northern blot analysis, CXCR3 is highly restricted to activated $\mathrm{T}$ cells and natural killer (NK) cells, and not to other leukocytes (14). Therefore IP-10 or Mig signaling appears to be an important mechanism for selective homing of activated/effector cells, which are known to accumulate preferentially at inflammatory sites (16), as well as in many tumors. IP-10 is expressed abundantly in various inflammatory lesions,

1. Abbreviations used in this paper: $\mathrm{CCR}, \mathrm{CC}$ chemokine receptor; CXCR, CXC chemokine receptor; MCP, monocyte chemotactic protein; MIP, macrophage inflammatory protein; NK, natural killer; $\left[\mathrm{Ca}^{+}\right] \mathrm{i}$, intracellular calcium concentration. 
particularly those characterized by $\mathrm{T}$ cell infiltration, such as delayed type hypersensitivity responses in skin (17), in EAE (18), and in transplants undergoing rejection (19).

Another chemokine receptor expressed by T cells is CCR5, the receptor for RANTES, macrophage inflammatory protein$1 \alpha(\mathrm{MIP}-1 \alpha)$, and MIP-1 $\beta$. CCR5 is expressed on activated and memory $\left(\mathrm{CD} 45 \mathrm{RO}^{+}\right) \mathrm{T}$ cells $(12,20)$, which correlates with the finding that memory and activated $\mathrm{T}$ cells, but not naive $\mathrm{T}$ cells, respond to RANTES, MIP- $1 \alpha$, and MIP-1 $\beta$ in chemotaxis assays $(21,22)$. In addition, RANTES, MIP- $1 \alpha$, and MIP-1 $\beta$ are expressed in many inflammatory lesions (23). The assumption has been that different chemokines will attract particular types of leukocytes based on the ligand specificity and expression patterns of the relevant receptors. For instance, CCR5 and CXCR4 are expressed on T cells in a largely reciprocal fashion (12), and probably facilitate the positioning of two types of $\mathrm{T}$ cells in different tissues.

We now report on the distribution of CXCR3 and CCR5, particularly their association with inflammation. A striking finding was the high proportion of $\mathrm{CXCR}^{+}$and $\mathrm{CCR} 5^{+} \mathrm{T}$ cells in certain inflammatory lesions, compared with relatively low levels of $\mathrm{CXCR}^{+}$and $\mathrm{CCR}^{+} \mathrm{T}$ cells in blood or lymph node. In the blood, CXCR3, as well as CCR5, was expressed on a subset of circulating $\mathrm{CD} 45 \mathrm{RO}^{+}$and $\beta 1$ integrin ${ }^{\text {hi }} \mathrm{T}$ cells, a phenotype consistent with previous activation. Moreover, the $\mathrm{CCR}^{+}$subset was contained entirely within the $\mathrm{CXCR}^{+}$subset. We conclude that these two chemokine receptors mark the majority of T cells within inflamed tissues, as well as peripheral blood $\mathrm{T}$ cells with a predilection for homing to these sites.

\section{Methods}

Cells, cell lines, and tissue culture. Normal human blood leukocytes were isolated as described (24). To generate CD3 blasts, $2 \times 106$ $\mathrm{PBMC} / \mathrm{ml}$ in RPMI 1640 plus $10 \%$ FCS were added to tissue culture plates first coated with the anti-CD3 antibody TR66. After 4-6 d, blasts were removed to fresh media and supplemented with IL-2 (kindly provided by Antonio Lanzavecchia, Basel Institute for Immunology, Basel, Switzerland) at $50 \mathrm{U} / \mathrm{ml}$. Other cell lines used included transfectants of the L1.2 murine pre B cell lymphoma, expressing high levels of either CXCR3 (this report), CXCR1 (25), CXCR2 (25), CCR2b, CCR4, CCR5 (26), or CCR1 (27). CXCR3 cDNA was obtained by PCR using a 5 '-oligonucleotide primer and $3^{\prime}$-oligonucleotide primer which contained flanking XhoI and XbaI sites respectively. The PCR fragment was subcloned into the XhoI-XbaI sites of pCDNA3 (Invitrogen Corp., San Diego, CA), and the inserted gene was driven by a CMV promoter. Stable transfection of the DNA into a murine pre B lymphoma cell line (L1.2) was obtained as described (24). The cell surface expression of CXCR3 was monitored by ligand binding and Scatchard analysis. Transfectants were maintained in RPMI 1640 supplemented with $10 \%$ bovine serum and $800 \mu \mathrm{g} / \mathrm{ml} \mathrm{G} 418$.

$m A b$ production and flow cytometry. mAbs reactive with CXCR3 were generated by immunizing BALB/C mice with $10 \mu \mathrm{g}$ of a 37-mer synthetic peptide corresponding to the first $37 \mathrm{NH}_{2}$-terminal amino acids of CXCR3 (14), five times over a period of $10 \mathrm{wk}$. This peptide was synthesized and coupled to purified protein derivative of tuberculin by the manufacturer (Severn Biotech Ltd., Kidderminster, United Kingdom). The first immunization was intraperitoneal with CFA, the second, third, and fourth were intraperitoneal with IFA, and the final immunization was intravenous with protein alone. $4 \mathrm{~d}$ after the last immunization, the spleen was taken and cell fusion performed using the cell line SP2/O, as described (28). Specific mAbs reactive with CXCR3 were identified using untransfected and CXCR3 transfected L1.2 cells, and immunofluorescent staining and analysis using a FACScan ${ }^{\circledR}$ (Becton Dickinson, Mountain View, CA). The main $\mathrm{mAb}$ used in this study termed $1 \mathrm{C} 6$, is of isotype IgG1. Anti-CXCR3 mAbs were also generated by immunizing mice with CXCR3/L1-2 transfectant, in a similar manner to that described for anti-CCR3 and anti-CCR5 $(20,29)$.

mAbs to CCR5 have been described (20). PE-conjugated mAbs to CD4, CD8, CD14, CD19, CD25, CD26, CD29, CD69, CD45RO, CD45RA, and CD95 were supplied by PharMingen (San Diego, CA). To assess reactivity of mAbs against transfected cells or leukocytes, indirect immunofluorescence and flow cytometry were used. Cells were washed once with PBS, and resuspended in $100 \mu$ l PBS containing $2 \%$ human serum and $0.1 \%$ sodium azide (staining buffer), $5 \mu \mathrm{g} /$ $\mathrm{ml}$ purified antibody, $5 \mu \mathrm{g} / \mathrm{ml}$ isotype matched control mAb (Sigma Chemical Co., St. Louis, MO) or $50 \mu$ l hybridoma culture supernatant. After $20 \mathrm{~min}$ at $4^{\circ} \mathrm{C}$, cells were washed twice with staining buffer, and resuspended in $50 \mu$ l FITC-conjugated affinity purified $\mathrm{F}\left(\mathrm{ab}^{\prime}\right) 2$ goat anti-mouse IgG (Jackson ImmunoResearch Labs., Inc., West Grove, PA). After 20 min, cells were washed twice in staining buffer and analyzed on the FACScan ${ }^{\circledR}$ to determine the level of surface expression. Propidium iodide was used to exclude dead cells. For multicolor analysis, PE- or FITC-conjugated mAbs were used together with biotinylated anti-CXCR3 mAb 1C6 to stain cells. After washing, the cells were incubated with Streptavidin-Red 670 (GIBCO BRL, Gaithersburg, MD). The results were analyzed by FACScan ${ }^{\circledR}$ using electronic gating and compensation.

Chemokines, chemotaxis assays, and ligand-binding assay. Recombinant human chemokines were obtained from PeproTech, Inc. (Rocky Hill, NJ). Chemotaxis of CD3 blasts was assessed using a modification of a transendothelial assay (7), using the cell line ECV304 as described (24). Cells that had migrated to the bottom chamber were placed in a tube, and relative cell counts were obtained using the FACScan ${ }^{\circledR}$.

${ }^{125}$ I-labeled chemokines were obtained from DuPont-NEN (Boston, MA). The functional activity of radiolabeled IP-10 was tested in chemotaxis assays and was found to have $80 \%$ activity of unlabeled IP-10 (data not shown). Chemokine binding to target cells was carried out as described previously (24). Briefly, cells were resuspended in binding buffer ( $50 \mathrm{mM}$ Hepes, $1 \mathrm{mM} \mathrm{CaCl}_{2}, 5 \mathrm{mM} \mathrm{MgCl}_{2}, 0.5 \%$ BSA) and incubated with radiolabeled ligand in the presence or absence of inhibitors. After $60 \mathrm{~min}$ at $37^{\circ} \mathrm{C}$, cells were washed three times in binding buffer supplemented with $0.5 \mathrm{~N} \mathrm{NaCl}$ and pellets were counted. All experiments were repeated at least three times. Curve fit and concentrations that inhibit 50\% specific binding (IC50) were calculated by KaleidaGraph software (Synergy Software, Inc., Reading, PA). Scatchard Plot analysis was carried out using Microsoft Excel.

Tissues and immunohistochemistry. Human tissues (normal and inflamed colon and vagina) were obtained from the National Disease Research Institute, a service organization funded by the National Institutes of Health. Synovial fluid was obtained from patients with rheumatoid arthritis.

Immunohistochemical analysis for CXCR3 was performed on frozen tissue samples. Briefly, tissue was sectioned at a thickness of $4 \mu \mathrm{m}$, desiccated, and then fixed in $2 \%$ paraformaldehyde $/ 0.5$ X PBS for 10 min at $4^{\circ} \mathrm{C}$. After PBS washing, nonspecific antibody binding sites were blocked with $10 \%$ normal goat serum $/ 5 \%$ human $\mathrm{AB}$ serum/ PBS for $30 \mathrm{~min}$ at room temperature. Next, the purified CXCR3 monoclonal antibody $1 \mathrm{C} 6$ was diluted to a concentration of $1 \mu \mathrm{g} / \mathrm{ml}$ in $0.3 \%$ Triton X-100/0.2\% Tween 20/1\% FCS/5\% human AB serum $/ 0.1 \%$ sodium azide and applied to tissue sections overnight at $4^{\circ} \mathrm{C}$. An isotype-matched irrelevant monoclonal antibody was used as a negative control on step sections of tissues (IgG1, MOPC21; Sigma Chemical Co.). Subsequently, biotinylated goat anti-mouse IgG (Vector Laboratories, Inc., Burlingame, CA) and avidin-biotin-alkaline phosphatase complexes (BioGenex Labs, San Ramon, CA) were added in sequence. Fast Red (BioGenex Labs), containing 2\% levamisol to block endogenous alkaline phosphatase activity, was used as the chromogen and Mayers hematoxylin as the counterstain. 


\section{Results}

CXCR3 is expressed by lymphocytes but not by other leukocyte types. $\mathrm{mAbs}$ have proven to be powerful tools for assessing the biology of various chemokine receptors $(6,25,29)$, particularly CCR5 $(12,20)$. To study the functions of one of the important $\mathrm{T}$ cell chemokine receptors, CXCR3, specific mAbs were generated by immunizing mice either with synthetic peptides or with CXCR3 transfected cells (see Methods). These mAbs reacted specifically with CXCR3, as judged by FACS ${ }^{\circledR}$ staining of CXCR3 transfected L1.2 cells, and not wild-type L1.2 cells or L1.2 cells transfected with numerous other receptors. (Fig. $1 A$ ). In peripheral blood, anti-CXCR3 mAbs were unreactive on neutrophils, monocytes, and eosinophils (not shown), as expected from previous analyses of CXCR3 expression by Northern blot, as well as functional responsiveness of cells to IP-10 (14). However the phenotypic analysis did reveal the expression of CXCR3 on a proportion of circulating lymphocytes (Fig. $1 B$, day 0), observed in all (>20) normal individuals examined. A feature of $\mathrm{CXCR} 3$, determined from previous studies on mRNA expression, is its expression on activated T cells (14). Staining of T cells activated by anti-CD3 confirmed that CXCR3 was expressed at high levels on these cells, but only after 5-8 d of activation, and in fact CXCR3 expression was downregulated immediately after activation (Fig. $1 B$, day 3 ). This pattern of expression and regulation was similar to that observed for CCR5 (Fig. $1 B$ ). Both CCR5 and CXCR3 were upregulated on long-term-activated IL-2-stimulated cells, and usually required 2-3 wk for peak expression (Fig. $1 B$, day 21).

CXCR3 expression is skewed to previously activated/memory lymphocytes, but shows a broader pattern of expression than CCR5. A two color immunofluorescence analysis of peripheral blood lymphocytes showed that it was mostly $\mathrm{CD}^{+}$ cells that expressed CXCR3, although a small proportion of $\mathrm{B}$ cells $\left(\mathrm{CD} 19^{+}\right)$and $\mathrm{NK}$ cells $\left(\mathrm{CD} 56^{+}\right)$also expressed this receptor (Fig. $2 \mathrm{~A}$ ). A three color analysis of $\mathrm{T}$ cells, performed using anti-CD3-FITC to label T cells, showed that a subset of both $\mathrm{CD}^{+}$cells and $\mathrm{CD}^{+}$cells expressed CXCR3. An analysis using markers of acute activation, such as CD25 and CD69, revealed that acutely activated T cells generally expressed this receptor, in contrast to CCR5 which is absent from such cells (12). $\mathrm{CXCR}^{+} \mathrm{T}$ cells were CD95 ${ }^{+}, \mathrm{CD}^{4} 5 \mathrm{RO}^{+}$, and CD45RA ${ }^{\text {low }}$, a phenotype consistent with previous activation. We next compared the expression of CXCR3 with that of CCR5, since in peripheral blood, CCR5 is also expressed predominantly on previously activated $\mathrm{T}$ cells (20). In all instances, $\mathrm{CCR}^{+}$cells were contained entirely within the $\mathrm{CXCR}^{+}$subset, with $\mathrm{CXCR} 3$ being always expressed on more cells than CCR5 (Fig. 2 B). The subset of B cells expressing CXCR3 was assessed by gating on CD19+ lymphocytes. In general, $\mathrm{CXCR}^{+} \mathrm{B}$ cells expressed higher levels of $\beta 1$ integrins, however there was no strong correlation with $\operatorname{IgD}$ or CD11a expression (Fig. $2 C$ ).

Activated T cell binding of IP-10 and chemotaxis is blocked by anti-CXCR3 $m A b$. In a previous study, IP-10 and Mig were found to signal through the chemokine receptor CXCR3 (14). To confirm that these two chemokines did in fact bind to CXCR3, and to gather information on the binding affinity and expression of CXCR3, studies were performed using radiolabeled IP-10. Fig. $3 A$ shows that ${ }^{125}$ I-labeled IP-10 bound to anti-CD3-activated, IL-2-stimulated T cells, and this binding could be inhibited with increasing concentrations of unlabeled IP-10. Scatchard analysis revealed a $\mathrm{K}_{\mathrm{d}}$ of $69 \mathrm{pM}$, and 11,000 receptors per cell (Fig. 3 A, insert). ${ }^{125}$ I-labeled IP-10 binding to activated $\mathrm{T}$ cells could also be totally inhibited by unlabeled Mig, with a $\mathrm{K}_{\mathrm{d}}$ of $90 \mathrm{pM}$ (Fig. $3 A$ ). To verify IP-10 indeed binds CXCR3, we carried out ligand binding assays using receptor transfectants. Only the CXCR3 transfected, but not parental L1.2 cells or other chemokine receptor transfected cells demonstrated significant binding activity to ${ }^{125}$ I-labeled IP-10, with a similar affinity to that observed on activated $\mathrm{T}$ cells (data not shown). Another evidence to support IP-10 binding specifically to CXCR3 was obtained by blocking IP-10 binding with anti-CXCR3 mAbs. The ability of mAb 1C6 to inhibit ${ }^{125}$ I-labeled IP-10 binding to activated T cells is shown in Fig. 3 B.

\section{A L1.2 Transfectants}

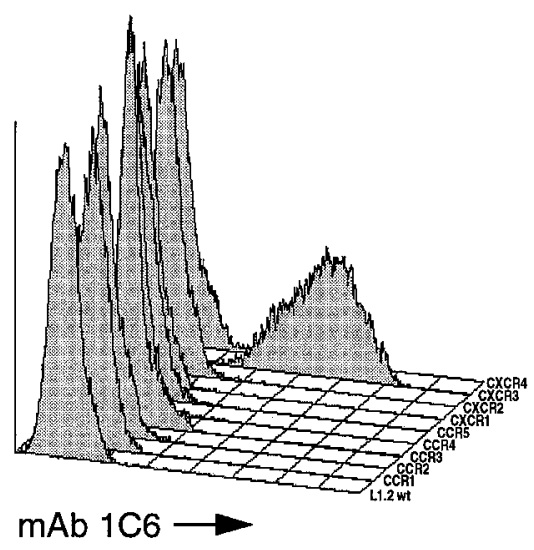

\section{B T cells}
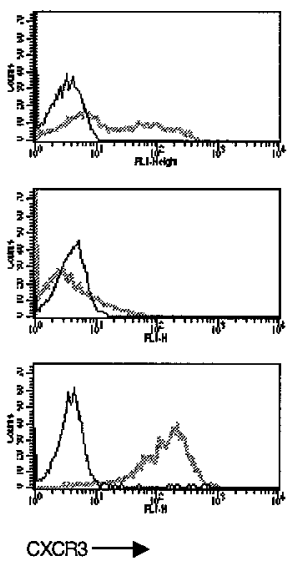
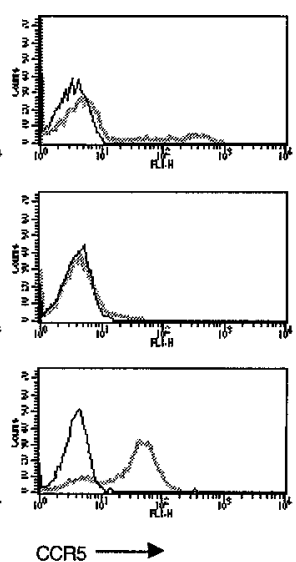

Figure 1. Identification of a CXCR3-specific $\mathrm{mAb}$, expression of CXCR3 on activated $\mathrm{T}$ cells, and comparison with expression of CCR5. $(A)$ mAb 1C6 staining of various L1.2 transfectants. Stable L1.2 transfectants expressing either CCR1, CCR2b, CCR3, CCR4, CCR5, CXCR1, CXCR2, CXCR3, and CXCR4 were stained with the anti-CXCR3 mAb 1C6. Negative control staining for all the L1.2 transfectants (not shown) resembled the staining shown for $1 \mathrm{C} 6$ on wt L1.2 cells. (B) Expression of CXCR3 and CCR5 on resting and activated T cells. Leukocyte subsets were identified in whole blood, by their forward angle and side scatter, and were gated accordingly. To gen-

erate $\mathrm{CD} 3$ blasts, PBMC were activated with anti-CD3 mAb, and were then maintained in media containing IL-2 for the indicated time periods. In each plot, the fainter profile represents staining with the anti-CXCR3 mAb 1C6, and the sharper profile staining with an isotype matched control $\mathrm{mAb}$. 


\section{A blood lymphocytes}
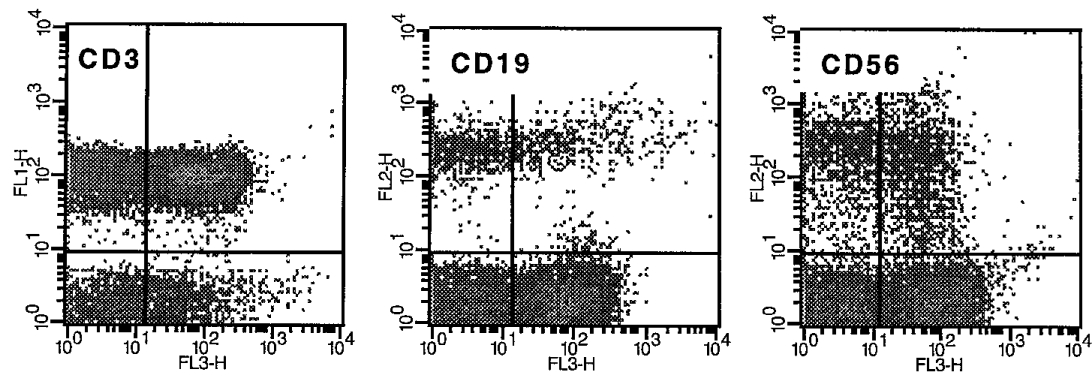

\section{B CD3 gated}
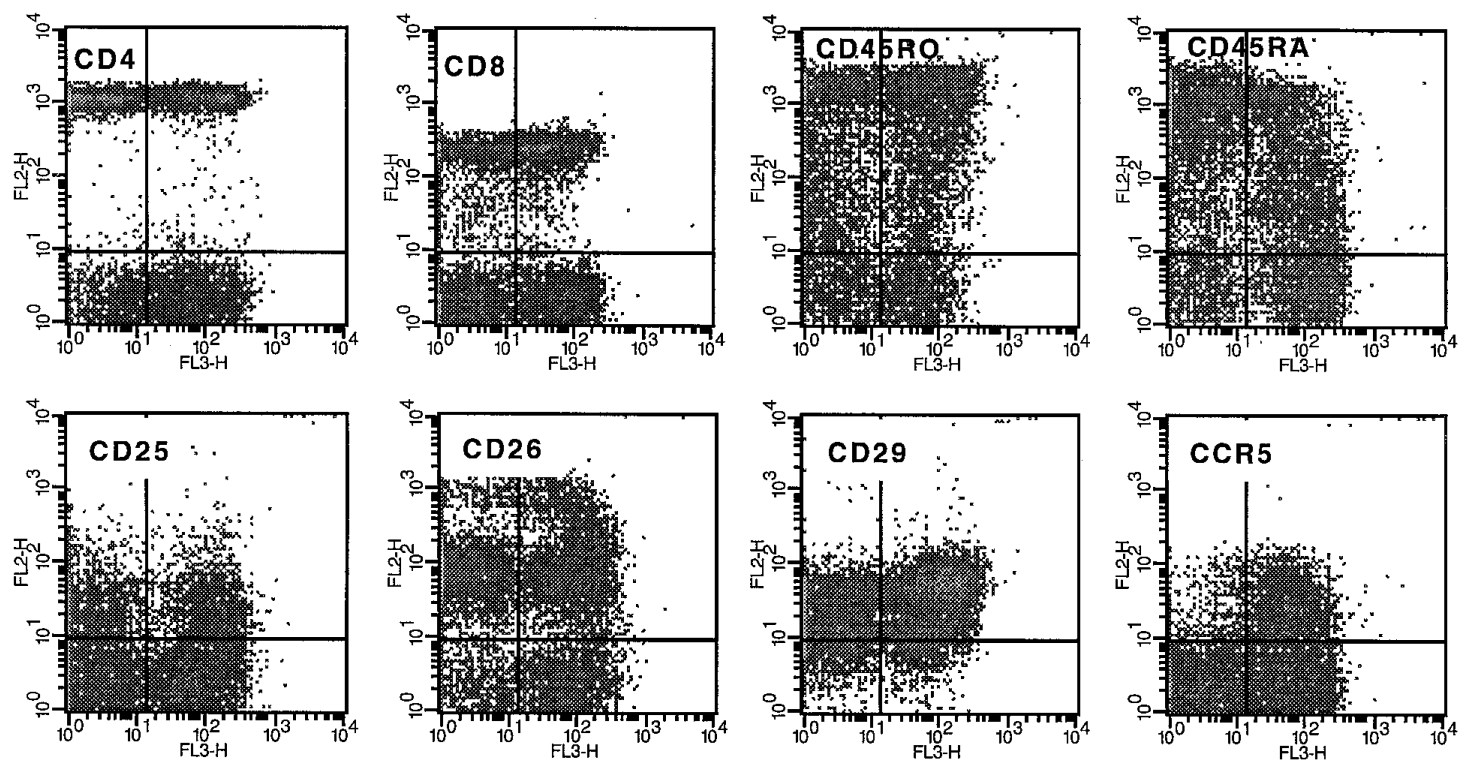

\section{CD19 gated}
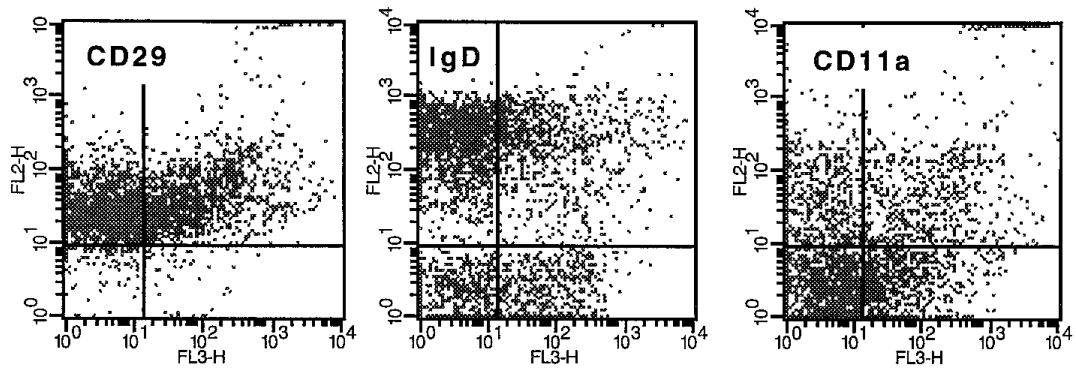

\section{CXCR3 expression}

Figure 2. CXCR3 expression on various populations of blood lymphocytes. $(A)$ Two color staining protocol was used to assess for expression of CXCR3 (horizontal axis) on T cells $\left(C D 3^{+}\right)$, B cells $\left(C D 19^{+}\right)$, and NK cells $\left(C D 56^{+}\right)$as displayed on the vertical axis. $(B)$ CXCR3 expression (horizontal axis) versus various markers (vertical axis), on the $\mathrm{CD}^{+}$subset of blood lymphocytes, analyzed by three color immunofluorescence. Anti-CD3 FITC was used to stain T cells, and these cells were gated electronically for analysis. $(C)$ CXCR3 expression on B cells $\left(C D 19^{+}\right)$. Quadrants were set according to the staining of control mAbs. The staining shown was representative of five donors analyzed. 
A

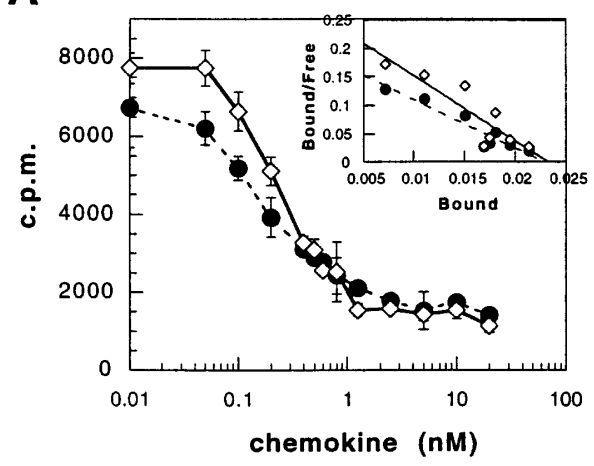

B

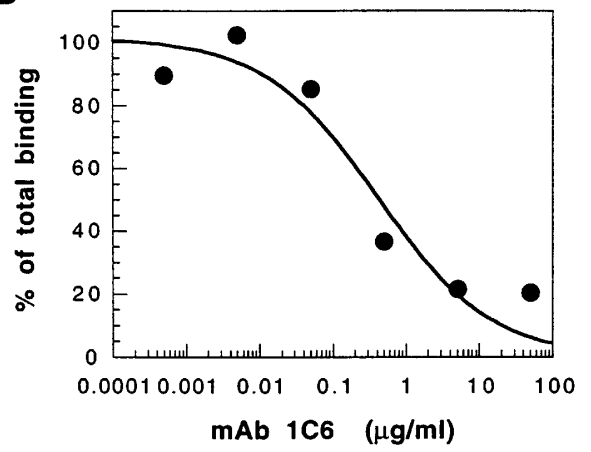

C

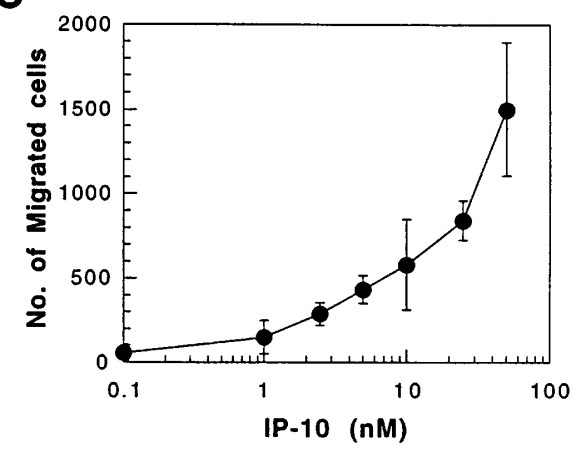

D

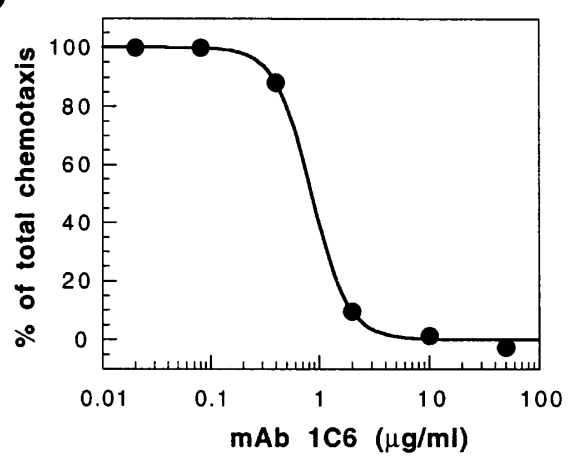

Figure 3. mAb 1C6 inhibition of IP10 binding and chemotaxis. $(A)$ High affinity binding of radiolabeled IP-10 to activated T cells. Human $T$ cells were activated by antiCD3 and IL-2 (CD3 blast cells) as described in Methods. The cells were incubated with $0.05 \mathrm{nM}$

${ }^{125}$-I labeled IP-10 in the presence of increasing concentrations of unlabeled IP-10 (diamonds) or Mig (circles). From the competitive binding curve, Scatchard plot was calculated (inset) which gave 11,000 receptors per cell when either unlabeled IP-10 or Mig was used. The $K_{\mathrm{d}} \mathrm{s}$ are $69 \mathrm{pM}$ for IP-10 (diamonds), and $90 \mathrm{pM}$ for Mig (circles). (B) mAb 1C6 inhibits ${ }^{125}$ I-IP-10 binding to activated T cells. CD3 blasts were incubated with $0.05 \mathrm{nM}$ ${ }^{125} \mathrm{I}-\mathrm{IP}-10$ in the presence of increasing concentrations of $1 \mathrm{C} 6$ as indicated. After $60 \mathrm{~min}$ at room temperature, cell pellets were washed and counted. The percentage of binding was calculated using the cpm of cells in the absence of $\mathrm{mAb}$ as $100 \%$. The mAb 1 C6 inhibited $50 \%$ of total binding at $160 \mathrm{ng} / \mathrm{ml}(\mathrm{IC} 50=160$ $\mathrm{ng} / \mathrm{ml}$ ). (C) IP-10 mediated chemo-

taxis of activated T cells. Human CD3 blast cells were used in transendothelial chemotaxis assay towards increasing concentrations of IP-10. After $1.5 \mathrm{~h}$, migrated cells were counted by flow cytometry. The number of cells in the absence of IP-10 was 57 . The error bars represent SD of duplicate samples. $(D)$ Inhibition of IP-10 mediated chemotaxis by anti-CXCR3 mAb. Human CD3 blast cell chemotaxis to $12.5 \mathrm{nM}$ IP-10 was carried out in the presence of increasing concentrations of purified anti-CXCR3 mAb 1C6. The percentage of total chemotaxis was calculated using the number of cells migrated in the absence of $\mathrm{mAb}$ as $100 \%$.

In this study, $5 \mu \mathrm{g} / \mathrm{ml}$ of $1 \mathrm{C} 6$ was sufficient to achieve a total inhibition of binding, and an IC50 was calculated to be $160 \mathrm{ng} / \mathrm{ml}$.

The high level expression of CXCR3 on activated T cells correlated with functional activities mediated by IP-10. In a transendothelial chemotaxis assay, activated $\mathrm{T}$ cells migrated to IP-10 in a dose-dependent fashion (Fig. $3 \mathrm{C}$ ). The number of migrated cells was similar to that induced by other $\mathrm{CC}$ chemokines known to induce $\mathrm{T}$ cell migration such as monocyte chemotactic protein-1 (MCP-1) or MIP-1 $\beta$, ligands for CCR2 and CCR5 respectively. IP-10-mediated chemotaxis was entirely due to its interaction with CXCR3, since it was completely inhibited by $10 \mu \mathrm{g} / \mathrm{ml}$ of mAb $1 \mathrm{C6}$ (Fig. $3 \mathrm{D}$ ). The potency of this mAb to block chemokines was similar to that of other anti-chemokine receptor blocking mAbs (29).

Predominance of $\mathrm{CXCR3}^{+}$and $\mathrm{CCR}^{+}$lymphocytes at inflammatory sites. Rheumatoid synovial fluid is a useful source of inflammatory cells for examining features of leukocyte recruitment and function. T cells from RA synovial fluid, as well as from other inflammatory sites, have a characteristic pheno-

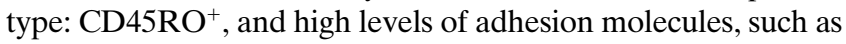
$\beta 1$ integrins. This is similar to the phenotype of most $\mathrm{CXCR}^{+}$ $\mathrm{T}$ cells in the blood. Lymphocytes from rheumatoid synovial fluid were assessed for CXCR3 and CCR5 expression, as well as a variety of other markers such as CD45RO. Fig. $4 A$ shows that synovial fluid $\mathrm{T}$ cells from an individual with RA were
97\% $\mathrm{CXCR}^{+}$, and $80 \% \mathrm{CCR}^{+}$, whereas blood $\mathrm{T}$ cells from the same individual, obtained at the same time, were only $35 \%$ $\mathrm{CXCR}^{+}$, and $15 \% \mathrm{CCR}^{+}$(Fig. 4 B). Similar results were obtained from three individual RA patients.

Microscopic examination of synovial biopsies from ten RA patients revealed multifocal, perivascular, variably sized accumulations of lymphocytes, lesser numbers of macrophages, and scattered neutrophils. Immunohistochemical analysis of the tissues revealed that in all biopsies, $>80 \%$ of perivascular lymphocytes were intensely immunoreactive for CXCR3 (Fig. 5 A). Lymphocytes distant from blood vessels were less intensely immunoreactive or unstained.

To determine if $\mathrm{CXCR}^{+}$lymphocytes were a prominent component of other inflammatory tissues, we performed immunohistochemical analyses of samples of chronically inflamed vaginal mucosa $(n=4)$ and colonic mucosa $(n=10)$. The vaginal samples consisted of intact squamous epithelium covering a submucosa that contained multifocal perivascular aggregates of lymphocytes, fewer macrophages and neutrophils, with lymphocytes scattered throughout the submucosa and vaginal epithelium. Immunohistochemical analysis of the tissue revealed that $>80 \%$ of perivascular lymphocytes (Fig. 5 B) and essentially $100 \%$ of the intraepithelial lymphocytes (not shown) were intensely immunoreactive for CXCR3. The colonic biopsy obtained from patients with ulcerative coli- 


\section{A synovial fluid lymphocytes}
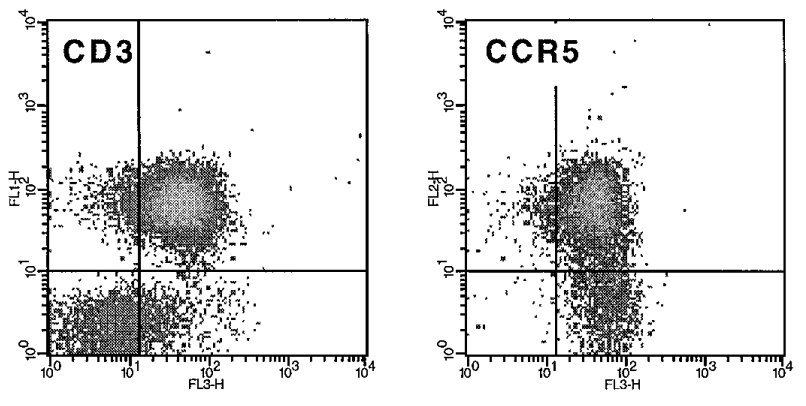

\section{B blood lymphocytes}
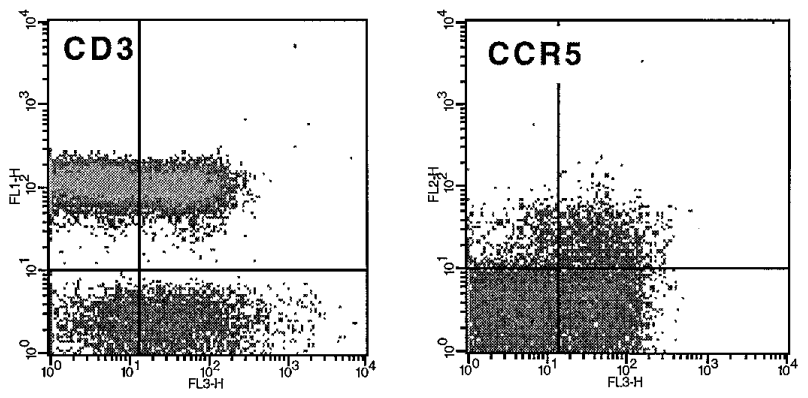

\section{CXCR3 Expression}

Figure 4. Expression of CXCR3 and CCR5 on synovial fluid T cells $(A)$ and blood T cells $(B)$ from rheumatoid arthritis patients. Synovial fluid lymphocytes and blood lymphocytes were stained for CXCR3, CCR5, and various other markers as described in Methods. Shown in the figure are CXCR3 staining versus CD3; and CXCR3 versus CCR5 gated on $\mathrm{CD}^{+}$cells. Quadrants were set based on control $\mathrm{mAb}$ staining. The staining shown was representative of three individuals analyzed.

tis, was characterized by focal ulceration of the colonic epithelium, and expansion of the lamina propria by large numbers of lymphocytes, fewer macrophages and neutrophils. Within the lamina propria infiltrate, $>70 \%$ of lymphocytes were immunoreactive for CXCR3, particularly below the area of epithelial ulceration. The actual proportion of cells expressing CXCR3 may be higher than this, since immunohistochemistry is not sensitive enough to detect low level receptor expression on the cell surface.

In contrast to inflamed tissues, a much lower percentage of T cells in normal lymph node expressed CXCR3 (Fig. 5 D). Approximately $20-30 \%$ of lymphocytes in the paracortex and medullary rays were immunoreactive for CXCR3, but only rare cells within cortical follicles were immunoreactive. Scattered CXCR3 immunoreactive lymphocytes were also identified within the subcapsular and medullary sinusoids. Other cell types such as smooth muscle, endothelium, and fibroblasts were uniformly nonimmunoreactive. CCR5 immunoreactive lymphocytes were fewer in number but similarly distributed. In contrast to CXCR3, CCR5 was expressed on medullary macrophages, as reported previously (20), endothelium and vascular smooth muscle (Rottman, J.B., unpublished observations).

\section{Discussion}

Lymphocytes migrate through the body in a nonrandom fashion $(2,16)$. One of the best examples of this is the selective migration of activated/memory $\mathrm{T}$ cells to certain tissues and inflammatory lesions $(30,31)$. Activated and memory $\mathrm{T}$ cells express higher levels of some adhesion molecules that facilitate their binding to inflamed endothelium. Nevertheless, in many cases, the expression of adhesion molecules, per se, fails to explain the selectivity of a leukocyte for a particular tissue or microenvironment. The chemokines and their receptors represent another layer where selectivity can operate, possibly in combination with adhesion mechanisms. Some chemokine receptors are expressed on leukocytes in a highly restricted manner, notably CCR3, the eotaxin receptor, on eosinophils, basophils, TH2 cells $(29,32,33)$, and the IL- 8 receptors on neutrophils $(6,34)$. Just how important the chemokine system is for the selective localization of leukocyte subsets is uncertain, although inhibition of chemokines has profound effects on certain inflammatory reactions (23).

Given that chemokine receptors play a fundamental role for leukocyte migration, attention has focused on identifying relevant receptors on $\mathrm{T}$ cells. Until now, analyses of the precise role of various chemokine receptors on $\mathrm{T}$ cells has been difficult, since specific reagents have not been available. In this study, we identified, at the protein level, one of the important chemokine receptors for $\mathrm{T}$ cells, CXCR3. In earlier studies, Northern blot analysis indicated that CXCR3 was restricted to activated T cells (14). Staining of blood leukocytes with mAbs to $\mathrm{CXCR} 3$ revealed, however, that CXCR3 is much more widely expressed, for example on blood $\mathrm{T}$ cells, and a small proportion of B cells and NK cells. It is possible that the CXCR3 protein was produced during previous activation and remains displayed on, but no longer actively synthesized by peripheral blood lymphocytes. $\mathrm{T}$ cells activated in vitro express particularly high levels of CXCR3, which fits with our findings that IP-10 is one of the most potent chemoattractants for these cells, together with MCP-1 and the CCR5 ligands RANTES, MIP- $1 \alpha$, and MIP-1 $\beta$. In fact, expression and regulation of CXCR3 were similar to that of CCR5, since both were found to be expressed by activated/memory T cells, and both showed the same pattern of downregulation and upregulation after $\mathrm{T}$ cell activation and IL-2 stimulation.

CXCR3 and CCR5 appear to mark subsets of lymphocytes with a capacity for migration to inflammatory sites. Identifying the nature of this lymphocyte subset is important for understanding the cellular and molecular mechanisms of inflammation, and for designing strategies for immunosuppression. $\mathrm{CXCR}^{+}$and $\mathrm{CCR}^{+} \mathrm{T}$ cells in blood are generally $\beta 1$ integrinhi ${ }^{\text {hi }} \mathrm{CD}_{45 \mathrm{RO}^{+}}, \mathrm{CD}_{45 \mathrm{RA}^{\text {low }}}$, a phenotype consistent with previous activation. The $\mathrm{T}$ cells that infiltrate the inflamed synovium are also $\beta 1$ integrin ${ }^{\text {hi }}, \mathrm{CD}_{45 \mathrm{RO}^{+}}, \mathrm{CD}_{45 \mathrm{RA}^{\text {low }}}(30,35)$, and also $\mathrm{CXCR}^{+}$and mostly $\mathrm{CCR}^{+}$(this study). We still need to determine whether the actions of IP-10 or Mig, resulting in the recruitment of $\mathrm{CXCR}^{+}$lymphocytes, is the reason for the distinctive phenotype of migrating cells, or whether another chemokine such as a CCR5 ligand is responsible. An alternative explanation for the high expression of CXCR3 or CCR5 on inflammatory cells is upregulation by inflammatory 


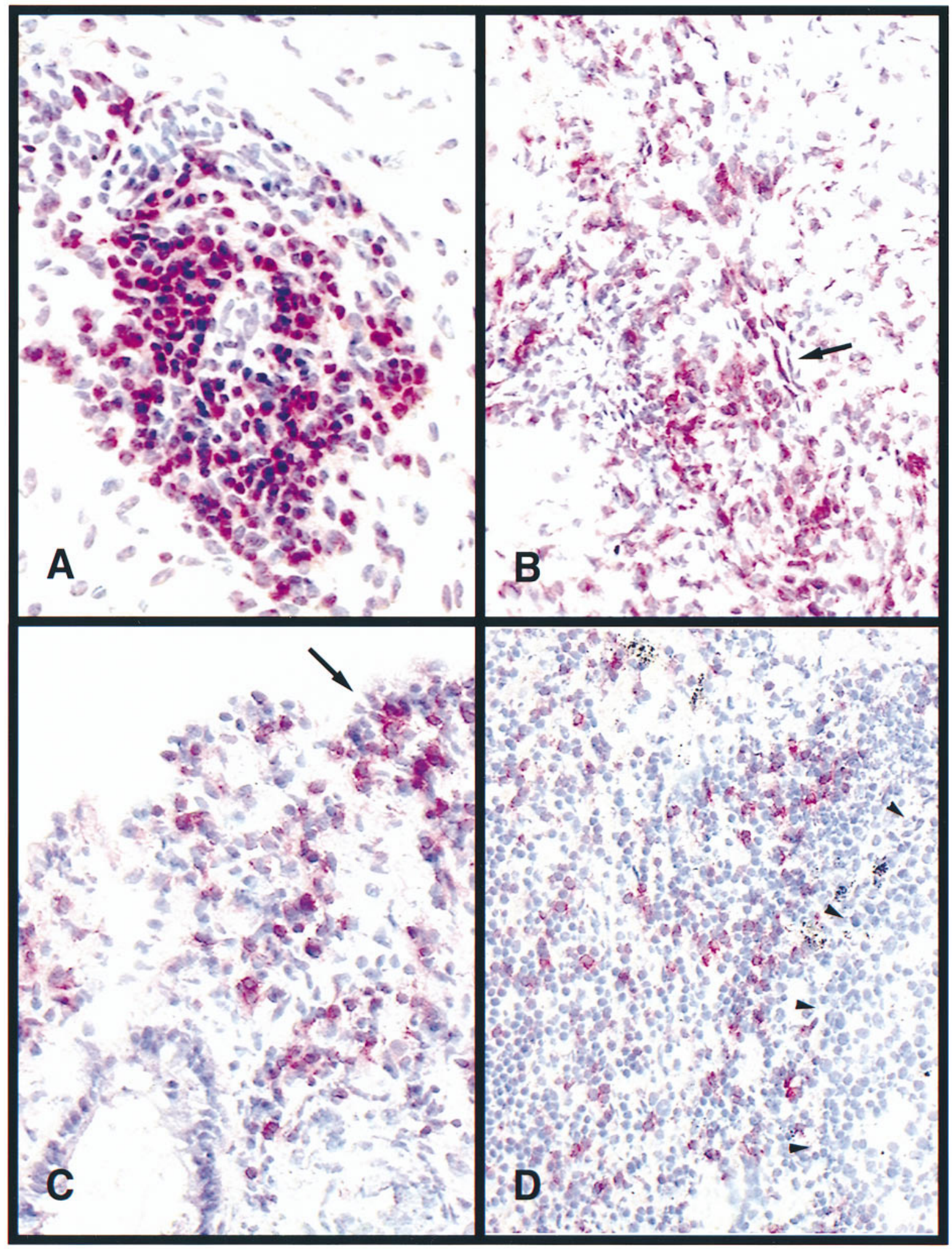

Figure 5. Enrichment of CXCR3 ${ }^{+}$lymphocytes in inflamed tissues. (A) Immunohistochemical detection of CXCR3 in a synovial biopsy from a patient with rheumatoid arthritis. A small blood vessel is surrounded by a thick aggregate of CXCR3 immunoreactive lymphocytes; $\times 200$. $(B)$ Immunohistochemical detection of CXCR3 in chronic vaginitis. Numerous CXCR3 immunoreactive lymphocytes are present in the perivascular space (arrow) and adjacent stroma; $\times 100$. (C) Immunohistochemical detection of CXCR3 in ulcerative colitis. The superficial lamina propria contains numerous $\mathrm{CXCR}^{+}$lymphocytes immediately beneath an area of discontinuous colonic epithelium (arrow); $\times 200$. (D) CXCR3 Expression in a normal human lymph node. $\mathrm{CXCR}^{+}$cells are scattered throughout the paracortex. Rare $\mathrm{CXCR}^{+}$cells are present within lymphoid follicles (arrowheads). 
cytokines, after extravasation. However, perivascular expression of CXCR3 (Fig. 5) and CCR5 (not shown) at the sites of inflammation and our finding that upregulation of CXCR3 and CCR5 in vitro takes many days would argue against these receptors being upregulated at the site of inflammation.

Blocking interaction of chemokines and their receptors should be useful therapeutically in autoimmune diseases or transplant rejection, in which particular receptors and their ligands may be responsible for the recruitment of cells. We have generated mAbs that effectively block CCR3 (29), CXCR1 (25), CXCR2 (25), and CCR5 (36). There is as yet no clarity on how chemokines bind to their 7-transmembrane receptors, although RANTES, MIP- $1 \alpha$, and MIP-1 $\beta$ have been found to bind to CCR5 through the second extracellular loop, and this can be blocked totally with a mAb specific for this loop (36). The anti-CXCR3 mAb 1C6 was able to inhibit completely the binding and chemotactic activity of IP-10 on activated T cells. $\mathrm{mAb} 1 \mathrm{C} 6$ is directed to the first 37 residuals of the $\mathrm{NH}_{2}$ terminus, and so this region is of particular importance for ligand binding. Reactivity of 1C6 with shorter synthetic peptides narrowed the epitope to the first 15 amino acids (Qin, S., unpublished observations). The $\mathrm{NH}_{2}$-terminal regions of CXCR1 and CXCR2 are also critical for IL-8 binding $(25,37)$, and the $\mathrm{NH}_{2}$-terminal region of CCR2b is sufficient in itself to bind MCP-1 (38).

In conclusion, we have established that CXCR3 is expressed abundantly on human T cells, and particularly on those $\mathrm{T}$ cells associated with activation and inflammation, and the expression of CXCR3 closely resembled that of CCR5. We anticipate that an understanding of the role of these two receptors in inflammatory diseases, particularly those with a strong T cell involvement should help in the design of therapies to inhibit leukocyte recruitment and suppress adverse inflammatory reactions.

\section{Acknowledgments}

We thank Dr. Walter Newman and Dr. Craig Gerard for advice during the course of these experiments, Dr. Ian Clark-Lewis for the supply of certain chemokines, and Dr. Jim Campbell, Dr. Paul Ponath, Dr. Lijun Wu, and Dr. Greg LaRosa for various L1.2 chemokine receptor transfectants.

\section{References}

1. Springer, T.A. 1994. Traffic signals for lymphocyte recirculation and leukocyte emigration: the multistep paradigm. Cell. 76:301-314.

2. Butcher, E.C., and L.J. Picker. 1996. Lymphocyte homing and homeostasis. Science. 272:60-66.

3. Baggiolini, M., B. Dewald, and B. Moser. 1997. Human chemokines: an update. Annu. Rev. Immunol. 15:675-705.

4. Mackay, C.R. 1997. Chemokines: what chemokine is that? Curr. Biol. 7 : R384-R386.

5. Moser, B., M. Loetscher, L. Piali, and P. Loetscher. 1997. Lymphocyte responses to chemokines. Int. Rev. Immunol. In press.

6. Qin, S., G. LaRosa, J.J. Campbell, H. Smith-Heath, N. Kassam, X. Shi, L. Zeng, E.C. Butcher, and C.R. Mackay. 1996. Expression of monocyte chemoattractant protein-1 and interleukin-8 receptors on subsets of T cells: correlation with transendothelial chemotactic potential. Eur. J. Immunol. 26:640-647.

7. Carr, M.W., S.J. Roth, E. Luther, S.S. Rose, and T.A. Springer. 1994. Monocyte chemoattractant protein 1 acts as a T-lymphocyte chemoattractant. Proc. Natl. Acad. Sci. USA. 91:3652-3656.

8. Taub, D.D., P. Proost, W.J. Murphy, M. Anver, D.L. Longo, J. van Damme, and J.J. Oppenheim. 1995. Monocyte chemotactic protein-1 (MCP-1), -2 , and -3 are chemotactic for human T lymphocytes. J. Clin. Invest. 95:13701376.

9. Bleul, C.C., R.C. Fuhlbrigge, J.M. Casasnovas, A. Aiuti, and T.A.
Springer. 1996. A highly efficacious lymphocyte chemoattractant, stromal cellderived factor 1 (SDF-1). J. Exp. Med. 184:1101-1110.

10. Bleul, C.C., M. Farzan, H. Choe, C. Parolin, I. Clark-Lewis, J. Sodroski, and T.A. Springer. 1996. The lymphocyte chemoattractant SDF-1 is a ligand for LESTRE/fusin and blocks HIV-1 entry. Nature. 382:829-833.

11. Oberlin, E., A. Amara, F. Bachelerie, C. Bessia, J.-L. Virelizier, F. Arenzana-Seisdedos, O. Schwartz, J.-M. Heard, I. Clark-Lewis, D.F. Legler, M. Loetscher, M. Baggiolini, and B. Moser. 1996. The CXC chemokine SDF-1 is the ligand for LESTR/fusin and prevents infection by T cell line-adapted HIV-1. Nature. 832:833-835.

12. Bleul, C.C., L. Wu, J.A. Hoxie, T.A. Springer, and C.R. Mackay. 1997. The HIV coreceptors CXCR4 and CCR5 are differentially expressed and regulated on human T lymphocytes. Proc. Natl. Acad. Sci. USA. 94:1925-1930.

13. Taub, D.D., A.R. Lloyd, K. Conlon, J.M. Wang, J.R. Ortaldo, A. Harada, K. Matsushima, D.J. Kelvin, and J.J. Oppenheim. 1993. Recombinant human interferon-inducible protein 10 is a chemoattractant for human monocytes and T lymphocytes and promotes T cell adhesion to endothelial cells. $J$. Exp. Med. 177:1809-1814.

14. Loetscher, M.L., B. Gerber, P. Loetscher, S.A. Jones, L. Piali, I.C. Lewis, M. Baggiolini, and B. Moser. 1996. Chemokine receptor specific for IP10 and Mig: structure, function and expression in activated T lymphocytes. $J$. Exp. Med. 184:963-969.

15. Liao, F., R.L. Rabin, J.R. Yannelli, L.G. Koniaris, P. Vanguri, and J.M. Farber. 1995. Human Mig chemokine: biochemical and functional characterization. J. Exp. Med. 182:1301-1314.

16. Mackay, C.R. 1993. Homing of naive, memory and effector lymphocytes. Curr. Opin. Immunol. 5:423-427.

17. Kaplan, G., A.D. Luster, G. Hancock, and Z.A. Cohn. 1987. The expression of a $\gamma$ interferon-induced protein (IP-10) in delayed immune responses in human skin. J. Exp. Med. 166:1098-1108.

18. Ransohoff, R.M., T.A. Hamilton, M. Tani, M.H. Stoler, H.E. Shick, J.A. Major, M.L. Estes, D.M. Thomas, and V.K. Tuohy. 1993. Astrocyte expression of mRNA encoding cytokines IP-10 and JE/MCP-1 in experimental autoimmune encephalomyelitis. FASEB (Fed. Am. Soc. Exp. Biol.) J. 7:592-600.

19. Kondo, T., A.C. Novick, H. Toma, and R.L. Fairchild. 1996. Induction of chemokine gene expression during allogeneic skin graft rejection. Transplantation (Baltimore). 61:1750-1757.

20. Wu, L., W.A. Paxton, N. Kassam, N. Ruffing, J.B. Rottman, N. Sullivan, H. Choe, J. Sodroski, W. Newman, R.A. Koup, and R.C. Mackay. 1997. CCR5 levels and expression pattern correlate with infectability by macrophage-tropic HIV-1 in vitro. J. Exp. Med. 185:1681-1691.

21. Schall, T.J., K. Bacon, K.J. Toy, and D.V. Goeddel. 1990. Selective attraction of monocytes and T lymphocytes of the memory phenotype by cytokine RANTES. Nature. 347:669-671.

22. Taub, D.D., K. Conlon, A.R. Lloyd, J.J. Oppenheim, and D.J. Kelvin. 1993. Preferential migration of activated CD4+ and CD8+ T cells in response to MIP-1 alpha and MIP-1 beta. Science. 260:355-358.

23. Strieter, R.M., T.J. Standiford, G.B. Huffnagle, L.M. Colletti, N.W. Lukacs, and S.L. Kunkel. 1996. "The good, the bad, and the ugly." The role of chemokines in models of human disease. J. Immunol. 156:3583-3586.

24. Ponath, P.D., S. Qin, D.J. Ringler, I. Clark-Lewis, J. Wang, N. Kassam, H. Smith, X. Shi, J.-A. Gonzalo, W. Newman, et al. 1996. Cloning of the human eosinophil chemoattractant, eotaxin: expression, receptor binding and functional properties provide a mechanism for the selective recruitment of eosinophils. J. Clin. Invest. 97:604-612.

25. Wu, L., N. Ruffing, X. Shi, W. Newman, D. Soler, C.R. Mackay, and S. Qin. 1996. Discrete steps in binding and signaling of interleukin-8 with its receptor. J. Biol. Chem. 271:31202-31209.

26. Wu, L., N. Gerard, R. Wyatt, H. Choe, C. Parolin, N. Ruffing, A. Borsetti, A.A. Cardoso, E. Desjardin, W. Newman, et al. 1996. CD4-induced interaction of primary HIV-1 gp120 glycoproteins with the chemokine receptor CCR-5. Nature. 384:179-183.

27. Campbell, J.J., S. Qin, K.B. Bacon, C.R. Mackay, and E.C. Butcher. 1996. The biology of chemokine and classical chemoattractant receptors: differential requirements for adhesion-triggering versus chemotactic responses in lymphoid cells. J. Cell Biol. 134:255-266.

28. Coligan, J.E., A.M. Kruisbeek, D.H. Margulies, E.M. Shevach, and W. Strober. 1992. Current Protocols in Immunology. John Wiley and Sons, New York. 2.5.1-2.5.12.

29. Heath, H., S. Qin, P. Rao, L. Wu, G. LaRosa, N. Kassam, P. Ponath, and C.R. Mackay. 1997. Chemokine receptor usage by human eosinophils. The importance of CCR3 demonstrated using an antagonistic monoclonal antibody. $J$. Clin. Invest. 99:178-184.

30. Pitzalis, C., G. Kingsley, D. Haskard, and G. Panayi. 1988. The preferential accumulation of helper-inducer $\mathrm{T}$ lymphocytes in inflammatory lesions: evidence for regulation by selective endothelial and homotypic adhesion. Eur. J. Immunol. 18:1397-1404.

31. Salmi, M., D.P. Adrew, E.C. Butcher, and S. Jalkanen. 1995. Dual binding capacity of mucosal immunoblasts to mucosal and synovial endothlium in humans: dissection of the molecular mechanisms. J. Exp. Med. 181:137-149.

32. Uguccioni, M., C.R. Mackay, B. Ochensberger, P. Loetscher, S. Rhis, G. LaRosa, P. Rao, P. Ponath, M. Baggiolini, and C.A. Dahinden. 1997. High ex- 
pression of the chemokine receptor CCR3 in human blood basophils. Role in activation by eotaxis, MCP-4 and other chemokines. J. Clin. Invest. 100:11371143.

33. Sallusto, F., C.R. Mackay, and A. Lanzavecchia. 1997. Selective expression of the eotaxin receptor CCR3 by human T helper 2 cells. Science. 277: 2005-2007.

34. Chuntharapai, A., J. Lee, C.A. Hebert, and K.J. Kim. 1994. Monoclonal antibodies detect different distribution patterns of IL-8 receptor A and IL-8 receptor B on human peripheral blood leukocytes. J. Immunol. 153:5682-5688.

35. Oppenheinmer-Marks, N., and P.E. Lipsky. 1997. Migration of naive and memory T cells. Immunol. Today. 18:456-457.

36. Wu, L., G. LaRosa, N. Kassam, C.J. Gordon, H. Heath, N. Ruffing, H.
Chen, J. Humblias, M. Samson, M. Parmentier, et al. 1997. Interaction of chemokine receptor CCR5 with its ligands: multiple domains for HIV-1 gp120 binding and a single domain for chemokine binding. J. Exp. Med. 186:13731381 .

37. Chuntharapai, A., J. Lee, J. Burnier, W.I. Wood, C. Hebert, and K.J. Kim. 1994. Neutralizing monoclonal antibodies to human IL-8 receptor A map to the NH2-terminal region of the receptor. J. Immunol. 152:1783-1789.

38. Monteclaro, F.S., and I. Charo. 1996. The amino-terminal extracellular domain of the MCP-1 receptor, but not the RANTES/MIP-1alpha receptor, confers chemokine selectivity. Evidence for a two-step mechanism for MCP-1 receptor activation. J. Biol. Chem. 271:19084-19092. 